\title{
Quality of diet received by the patient
}

\section{By Elizabeth Evans, Nutrition Department, Queen Elizabeth College, Campden Hill, London $W 8{ }_{7} A H$}

All those concerned with the welfare of patients in hospital would agree that a nutritionally adequate diet is a basic requirement for the well-being of the patient and to aid recovery. Indeed, hospitals aim to provide all the food necessary and do not require the patient to contribute towards his diet. Any foods consumed by the patient from his own private supplies are regarded as extras and luxuries but not essential for his over-all nourishment.

The potential nutritional value of hospital diets depends upon the amount and types of foods included in the menu and upon the way in which the food is prepared, cooked and served. The actual nutritional value of the diet will ultimately depend upon how much the patient eats, which in turn will be a reflection of food preferences, frequency of meals and appetite. Ideally, all factors work towards producing appetising and palatable meals attractively served. All too often, however, hospital food leaves much to be desired: food is badly cooked, sloppily and hastily served and does little to stimulate the patients often already jaded appetites. This has led to disquiet being voiced on the standards of hospital feeding in this country and the most comprehensive account resulted from the Nuffield Provincial Hospitals Trust survey in which the dietary practices of $15^{2}$ hospitals in England and Wales were investigated (Platt, Eddy \& Pellet, 1963). There are also recent reports of malnutrition amongst hospital patients in other countries (Leevy, Cardi, Frank, Gellere \& Baker, 1965; Bollet \& Owens, 1973; Butterworth, I974; Anderson, Iskasson \& Warnold, 1977). These reports have largely used biochemical parameters as determinants of nutritional status and not food intake. In this paper, however, I shall concentrate on the food intakes of patients both on normal hospital diets and on special therapeutic diets. Dietary surveys, like biochemical measurements, are, of course, only one aspect of the evaluation of nutritional status and cannot be used in isolation to diagnose the presence of malnutrition. Nevertheless, they can yield much useful information as to where the weaknesses are in the chain of people involved in the provision of food for the patient i.e. at which points bad feeding practices arise due to human or technical error, and how the nutritional status of patients can best be improved if necessary. I propose to examine the hospital diet firstly from the point of view of the quality of the diet as delivered to the ward including losses of nutrients during cooking, and secondly to look in more detail at levels of food intake in patients.

\section{Quality of food provided}

It is self-evident that the value of any diet depends on that diet actually being consumed and yet several surveys have shown that a third to half the food 
delivered to the wards is not served. The summary of results from three surveys is given in Table I. The wastage of food is high partly due to over provision, and partly because some dishes are not served, either because the ward staff overlook them or decide that the patients will not consume them. It is not necessarily a reflection of the quality of the food. One might expect that if more attention were paid to the food preferences of patients less food would be wasted. The study of food preferences of 400 patients from twenty-one hospitals in the United Kingdom, reported by Brown, Carden, Stanton \& Stock (1969), found that 'it would be impossible to please all the people all the time, but that a varied menu giving as wide a choice as possible was likely to please most of the people some of the time'. Glew (1970) found in his retrospective survey of discharged hospital patients that the provision of choice in the menu improved patients impression of the quality of the food. The current practice in many hospitals is increasingly to allow patients to select their choice of dishes from menus distributed usually a day in advance, and for meals to be delivered already plated out to the wards. These measures should do much to reduce food wastage, and the plating out of meals in the main kitchen is aesthetically more pleasing, both to the ward staff serving and to the patient receiving the food.

Table I. Percentage of food left over in serving dishes of all food sent for service

\begin{tabular}{|c|c|c|c|}
\hline \multicolumn{2}{|c|}{ 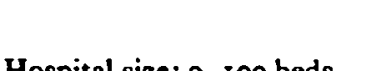 } & \% left over & Reference \\
\hline Hospital si & $\begin{array}{l}\text { e: } 0-100 \text { beds } \\
101-300 \text { beds } \\
301+\text { beds }\end{array}$ & $\begin{array}{l}24 \\
31 \\
3^{6}\end{array}$ & Platt et al (1963) \\
\hline $\begin{array}{l}\text { London } \\
\text { teaching } \\
\text { hospital }\end{array}$ & $\begin{array}{l}\text { Medical } \\
\text { wards }\end{array}$ & 32 & $\begin{array}{l}\text { Evans \& Stock } \\
\text { (unpublished) }\end{array}$ \\
\hline $\begin{array}{l}\text { Provincial } \\
\text { hospital }\end{array}$ & $\begin{array}{l}\text { Geriatric } \\
\text { wards }\end{array}$ & $\begin{array}{l}35 \\
44 \\
53\end{array}$ & $\begin{array}{c}\text { Evans \& Stock } \\
\text { (1971) }\end{array}$ \\
\hline
\end{tabular}

Large-scale catering procedures can affect the palatability of food, particularly of vegetables, and often results in the loss of the more labile nutrients. While this may not be very important for patients who are only in hospital for a short time, continued low intakes could lead to malnutrition in long-stay patients, especially if they enter hospital in a poor nutritional state. Since anorexia often accompanies disease it is important that the foods presented to the patients should have a high nutritional value. One of the conclusions of Platt et al. (1963) was that there was a tendency to over-cook vegetables and for meal service to be delayed such that these foods were unpalatable, with nearly complete destruction of vitamin C. Using vitamin $\mathrm{C}$ content as index of culinary standards, analysis of vegetable samples for vitamin C content in the surveys of Brown (1968) and Evans \& Stock (1971, 1972) also showed considerable losses of this vitamin during preparation, cooking and serving: these surveys having taken place some ro years after Platt et al. (1963) Evans \& Stock (unpublished) compared the vitamin $\mathrm{C}$ content of vegetables 
prepared in the main kitchen with those prepared in an adjacent diet kitchen, (Table 2). The vegetables in the diet kitchen were prepared and cooked much closer to the mealtime and losses of vitamin $\mathrm{C}$ were much lower as a result.

Table 2. Comparison of analysed results of vitamin $C$ content $(\mathrm{mg} / \mathrm{100} \mathrm{g})$ of some foods cooked in the diet kitchen with those cooked in the main kitchen

$\begin{array}{lccc}\text { Food } & \text { Main kitchen (A) } & \text { Diet kitchen (B) } & \begin{array}{c}\text { \% difference } \\ \text { B-A } \mathbf{A} \text { I00 }\end{array} \\ \text { Runner beans } & & & \mathbf{B} \\ \text { French beans } & 1 \cdot 4 & 2 \cdot 2 & 40 \\ \text { Cauliflower } & 1 \cdot 3 & 1 \cdot 9 & 32 \\ \text { Mixed vegetable salad } & 3 \cdot 7 & 36.5 & 90 \\ \text { Mashed potato } & 1 \cdot 4 & 1 \cdot 7 & 18 \\ \text { Boiled potato } & 1 \cdot 5 & 5.9 & 75 \\ \text { Peas } & 4 \cdot 0 & 6.6 & 39 \\ \text { Sprouts } & 1 \cdot 3 & 3.0 & 57 \\ \text { Spinach } & 20.0 & 38.0 & 47 \\ & 8.6 & 17.3 & 50\end{array}$

\section{Levels of intake}

It is well documented that energy requirements are raised during disease and trauma. Fleck (1971) quotes values of increase in energy expenditure of the order of $10-20 \%$ above basal metabolic rate for skeletal injuries, $15-50 \%$ in infections and $40-100 \%$ in burns. The pre-eminent nutritional requirement is for energy. If the diet is deficient in energy then the utilization of all other nutrients is adversely affected. Since the requirements for protein can also be higher than normal in order to ensure effective utilization of dietary protein the diet should not only contain sufficient good quality protein, but also be adequate in energy.

Hospital diets do contain enough good quality protein; the net dietary protein value of hospital diets expressed a NDP Cals\% was 9.6 in the sampled diets of Platt et al. (1963); 9.6 for the diet in a London teaching hospital (Evans \& Stock, unpublished), 9.2 and 9.5 for the diets in the geriatric surveys of Evans \& Stock (1971, 1972); these values compare well with the value of $8 \cdot 2$ for the average UK diet. The protein values of many hospital diets are not restricted by the total amount of protein but by the total energy intake. Platt et al. (1963) proposed a protein: energy scale for estimating requirements of hospital patients. Energy requirements are calculated by multiplying the basal metabolic energy requirements (BMR) by a factor. The factors for recuperative patients (the majority of patients on unrestricted diet when treatment is expected to lead to recovery) is BMR $\times 1.8$; and for maintenance patients (the long-stay chronically sick) BMR $\times 1 \cdot 5 \cdot$ The energy intakes of their 'sampled' patients for whom a I $d$ weighed intake was obtained, fell short of these standards; recuperative patients had intakes $16_{5}-$ I $70 \%$ of BMR, while maintenance patients had intakes $132-141 \%$ BMR. These intakes included the contribution made from the patients own supplies of food which amounted to some $15 \%$ of the total intake. Lower absolute energy intakes were found by Evans \& Stock in nearly all the age groups when individual weighed 
food intakes were made for up to 8 consecutive days (Table 3). The energy intakes, when expressed relative to BMR, were also much lower and in some cases barely met basal requirements (Table 4). Similar low-energy intakes have been found by Andersson et al. (1977) in patients of comparable age in Sweden. While for wellnourished individuals a short period of lowered energy intake may not be detrimental, in the long term they are clearly not desirable; poorly nourished individuals, of course, need special attention even in the short term.

Table 3. Energy intake in hospital patients: comparison between two surveys

$\begin{array}{lcccc}\begin{array}{c}\text { Age group } \\ \text { (years) }\end{array} & \begin{array}{c}\text { Evans \& Stock } \\ \text { (unpublished) }\end{array} & \begin{array}{c}\text { No. of } \\ \text { patients }\end{array} & \begin{array}{c}\text { Platt et al. } \\ \text { (1963) } \\ \text { (MJ/d) }\end{array} & \begin{array}{c}\text { No. of } \\ \text { patients }\end{array} \\ \begin{array}{l}\text { Recuperative } \\ \text { Women }\end{array} & \text { (MJ) } & & & \\ 20- & 7.52 & 5 & 9.05 & \\ 30- & 6.81 & 4 & 7.97 & 17 \\ 50- & 7.50 & 11 & 8.16 & 6 \\ 70+ & 5.99 & 6 & 6.87 & 3 \\ \text { Men } & 8.14 & 6 & 10.18 & 17 \\ 50-69 & & & & \\ \text { Maintenance } & & & & \\ \text { Women } & 6.77 & 1 & 6.68 & 13 \\ 50- & 6.38 & 1 & 6.93 & 18 \\ 70- & & & & \end{array}$

Table 4. Comparison of energy intakes with estimates of basal metabolism of patients in a London Teaching Hospital

$\begin{array}{ccccc}\begin{array}{c}\text { Age group } \\ \text { (years) }\end{array} & \begin{array}{c}\text { No. of } \\ \text { patients }\end{array} & \begin{array}{c}\text { Mean energy } \\ \text { intake } \\ (\mathrm{kcal}(\mathrm{kJ}) / 24 \mathrm{~h})\end{array} & \begin{array}{c}\text { Calculated basal } \\ \text { metabolism } \\ (\mathrm{kcal}(\mathrm{kJ}) / 24 \mathrm{~h})\end{array} & \begin{array}{c}\text { Energy } \\ \text { intake } \\ (\% \text { basal) }\end{array} \\ 20-29 & 5 & 1800(7560) & 1530(6426) & 118 \\ 29-49 & 4 & 1630(6846) & 1580(6636) & 103 \\ 50-59 & 7 & 2010(8442) & 1375(5675) & 146 \\ 60--64 & 4 & 1700(7140) & 1395(5859) & 122 \\ 65-69 & 6 & 1740(7308) & 1310(5502) & 133 \\ 70-79 & 5 & 1485(6237) & 1270(5334) & 117 \\ 80+ & 2 & 1350(5670) & 1355(5691) & 99\end{array}$

Even when the need to increase food intake has been recognized patients can be too ill to eat, and appetite is often decreased during illness; mild pyrexia has been shown by Evans \& Stock (1971) to reduce intake by half in one patient. Appetite usually increases during recovery and can be enhanced by good cooking, good nursing, tasteful presentation and service of meals. The value of good nursing care in the feeding of patients can be illustrated by reference to the long-stay patients, about whom there was the most concern, in the survey of Evans \& Stock (1971). These patients had higher intakes than the more active patients awaiting 
discharge. The differences arose because the long-stay patients required assistance with feeding, whereas the patients who were able to feed themselves often made poorer choices of food and ate rather slowly which may have inhibited them from consuming as much as they wished.

Recommendations for the improvement of the general hospital diet normally include a variety of measures such as better staffing in the wards, improved choice of foods and cooking methods, but few evaluations are reported in the literature. Following our dietary survey of a geriatric wing in a provincial hospital we made recommendations to improve the diet, and 2 years later conducted an evaluation survey (Evans \& Stock, 1972). We found that the hospital had implemented the new measures which resulted in significantly higher intakes of vitamin $C$, vitamin $A$ and vitamin D. However, over-all energy intakes were not improved. It must be emphasized that the implementation of any recommendation to improve the dietaries of patients ultimately depends on the ward staff who serve the food to the patients. This can be illustrated with reference to the daily provision of orange juice to improve vitamin $\mathrm{C}$ intake among these geriatric patients. Despite the apparent interest of all concerned with an orange-juice supplement and that a dietary survey was in progress, the orange juice was often not consumed by the patients. The ward staff sometimes forgot to distribute it, or the glass was placed on a bedside locker out of the reach of many patients, and some patients would have preferred the drink earlier in the day.

Further modification of the general hospital diet is required if higher energy intakes are to be achieved. Liquids are more easily tolerated by anorectic patients and it is interesting to note in this context that milk as a food provides a higher proportion of nutrients to the hospital diets than it does in the average UK diet (Evans \& Stock, 1971). More frequent distribution of milk or liquid formula meals such as Complan, for example at lunch and supper, are likely to improve over-all energy intakes. Evans \& Stock (1972) cite one patient who took Complan (provided from her own supplies) with her meals and by doing so increased her energy intake by half; her intake from hospital food was similar to that of other patients. Andersson et al. (1977) reported a similar $50 \%$ increase in energy intakes by the inclusion of liquid formula drinks into the general hospital diets for anorectic geriatric patients, and thereby restored these patients to positive nitrogen balance.

\section{Special diets}

Although the situation with regard to the general hospital diet leaves room for much improvement one might expect that the situation for patients on special diets to be better. A modified diet is an important part of therapy in many conditions such as obesity, diabetes, renal and hepatic conditions, and strict dietary control is assumed by the clinician in charge. However, a recent survey on 40 patients on reducing diets, carbohydrate-, protein-, or sodium-restricted diets found that many patients consumed more than the prescribed amount of nutrient (Davies, Evans, Stock \& Yudkin, 1975). The patients were selected from four hospitals each of which was equipped with a diet kitchen and employed at least one dietitian. The 
discrepancies between what was provided and what was consumed tended to be greater in those diets which left the patient hungry (reducing) or were unpalatable (carbohydrate- and sodium-restricted). These patients augmented their hospital diets with foods such as cream cakes, biscuits, confectionery, fruit and fruit drinks from their own supplies. A third of the total intake of one patient on reducing diet came from these foods. One sodium-restricted patient was observed to have twocourse meals brought into him by visitors and so his prescription for sodium was exceeded twelvefold. There was no control by nursing staff over food bought by patients from the mobile shop, brought in by visitors, or stored in the patients lockers.

The blame for not adhering to the prescribed diet cannot rest with the patient alone. For two-thirds of the patients studied, the food supplied by the hospital provided more than the prescribed amount of the nutrient. Most errors arose because the prepared diet was not given to the patient. Sometimes, the special diets were not delivered to the wards or were forgotten by the ward staff and so were not served. One patient was moved to another ward and was given the normal hospital diet for 2 days before it was realized he should be on special diet. Very rarely were the weighed milk allowances for the patients issued; their milk came from the main ward supplies. Disliked or unavailable foods were changed by the ward staff for other foods which were on occasion very different in composition. One protein-restricted patient was given a boiled egg as a substitute for tomato on toast; a sodium-restricted patient was given a kipper for breakfast; breakfast cereals with sugar and milk were frequently substituted for fruit juice or grapefruit. The low-sodium and low-protein breads which the patients disliked were regularly substituted with normal bread. Patients were also given foods because the ward staff had not been told they were forbidden or thought it important to withhold from the patient. Patients on reducing diets were often given, in addition to their weighed diets, a slice of bread, a bowl of soup, an extra portion of dessert or other foods from the main ward trolley by the ward staff.

These findings demonstrate the very low importance attached by nursing staff and patient alike to diet as a method of treatment. If a patient fails to respond to dietary treatment it is important to know whether the diet is ineffective or whether the patient was consuming quite a different diet. Non-treatment should not be interpreted as ineffectual treatment. It is disquieting to find that the hospital environment, seemingly the ideal place for diet therapy with the patient surrounded by highly skilled staff for advice and direction, can negate the expertise and work of the hospital dietitian. This situation clearly reveals the urgent need for the inclusion of training in human nutrition into medical and nursing curricula, if diet therapy is to play a significant role in the treatment of disease.

In conclusion, the discussion demonstrates very clearly that the most important people involved in the feeding of hospital patients are the ward staff who actually serve the food to the patient, and to whom the patient turns with regard to his dietary problems. The onus of seeing that the patients receive the right food increasingly falls on the ward staff, as the trend is to incorporate special diets into 
the normal hospital menu and for them to be prepared in the main kitchen. Improvement can come about only if the whole chain of people concerned, especially the ward staff, are made to understand that the treatment of some diseases by diet is as important as the treatment of other diseases by drugs, and that a good diet is a necessary adjunct for speedy recovery for all patients.

\section{REFERENCES}

Andersson, H., Isaksson, B. \& Warnold, T. (1977). Proc. 2nd Eur. Conf. Metab. 21, (Suppl. r) $34^{2}$.

Bollet, A. J. \& Owens, S. (1973). Am. F. Clin. Nutr. 26, 931.

Brown, A. M. (1968). In Vitamins and the Elderly, p. 93. [J. Exton-Smith, editor] Bristol: Scott Wright.

Brown, A. M., Carden, P. T., Stanton, B. R. \& Stock, A. L. (1969). Nutrition 23, 217.

Butterworth, C. E. (1974). F. Am. med. Ass. $230,879$.

Davies, G. J., Evans, E., Stock, A. L. \& Yudkin, J. (1975). Br. med. J. I, 200.

Evans, E. \& Stock, A. L. (1971). Nutr. Metab. 13, 21.

Evans, E. \& Stock, A. L. (1972). Nutrition 24, 87.

Fleck, A. (1971). Proc. Nutr. Soc. 30, 152.

Glew, G. (1970). Proc. Nutr. Soc. 29, 339.

Leevy, C. M., Cardi, L., Frank, O., Gellere, R. \& Baker, H. (1965). Am. J. Clin. Nutr. 1 7, 259.

Platt, B. S., Eddy, T. P. \& Pellet, P. L. (1963). Food in Hospitals Nuffield Procincial Hospitals Trust London: Oxford University Press. 